\title{
第36回内科学の展望 内科学におけるガイドラインとその検証
}

\section{9. 結核医療の基準と診療ガイドライン}

重藤えり子

Key words：結核医療の基準，標準治療，the International Standards for Tuberculosis Care

\section{1. なぜガイドラインでなく「結核医療の} 基準」なのか

結核は 2007 年に改正された感染症法の下で 2 類感染症であり, 喀痰検査で抗酸菌塗抹陽性等 周囲への感染の恐れが高い場合には入院が勧告 される。また治療中断は再発を招き, さらには 薬剤耐性結核の蔓延につながりかねないため, 患者本人だけでなく社会のためにも確実な治療 が行われるべき疾患である。そのため, 治療費 に対しては公費負担制度があり，公費支出のた めの基準として厚生労働省が専門家（結核病学 会）の見解を基に「結核医療の基準」を定めて いる，結核の治療に関して，ガイドラインより も厳しく守るべき範囲を定めているのが「結核 医療の基準」なのである.

これまで, 日本結核病学会は化学療法の進歩 などに対応して「結核医療の基準」に関する見 解を発表し，厚労省の「結核医療の基準」も昭 和 27 年に制定されて以来改正を重ねてきた. 最 近では 2002 年に, イソニアジド (INH) とリファ ンピシン（RFP）を軸に初期 2 カ月ピラジナミ ド（PZA）とエタンブトール（EB）またはスト レプトマイシン $(\mathrm{SM})$ を併用し全 6 カ月間で治 療終了する標準治療を強く勧める見解を発表し

しげとう えりこ：国立病院機構東広島医療センター
た ${ }^{1)}$. しかし, その後, 直接服薬確認療法 (Directly Observed Treatment, Short Course (DOTS))の 普及と発展に伴い, 間欠療法の必要性が高まっ たこと，また，2006 年にTuberculosis Coalition for Technical Assistance (TBCTA)（世界結核技 術支援連盟) が発表した結核医療の国際基準the International Standards for Tuberculosis Care (ISTC) との相違も検討する必要が生じたことか ら, 学会内で検討を重ね本年 4 月に「『結核医療 の基準』に関する見解一 2008 年 ${ }^{2)}$ を発表した.

なお, 結核病学会の示した見解と厚労省の「結 核医療の基準」は基本方針では一致しているが, 前回の見解から学会が抗結核薬として示したレ ボフロキサシン (LVFX) は, 結核への適応が承 認されていないため厚労省の基準には記載され ていない。世界的に多剂耐性結核の増加が危惧 されている中で, フルオロキノロン剂は治療薬 として必須のものとなっている. 特に, 超多剤 耐性結核への進展を防ぐためにフルオロキノロ ン剤は欠かせない薬剤である，結核医療の現場 でこれらの薬剤が適切に使用可能になるよう， 緊急の対応が望まれる。

結核は, 適切な化学療法によりほぼ治癒させ ることができる疾患となっている，しかし，感 染症としての側面が大きく，診療に際しても診 断・治療だけでなく, 感染対策, 患者管理等に も配慮が必要である。現在, 結核病学会では診 断と治療, 菌検査, 届出等を含む行政との連携 
や患者管理, 潜在性結核感染症への対応等を含 めた「結核診療ガイドライン」を作成中であり， 2009 年 7 月までには発表の予定である.

\section{2. 標準治療の原則}

初回治療例や, 薬剤耐性の可能性が低い再治 療例における標準治療は図に示すとおりである. INHとRFPの 2 剂を軸とし, 初期 2 カ月間PZA を使用する標準治療 $(\mathrm{A})$ と PAを使用せず治療 期間を 9 力月とする標準治療 (B) の 2 つを提示 している，世界の標準治療 ${ }^{3 \sim 5)}$ は（A）であり， PZAが使用できない場合にのみ $(\mathrm{B})$ の方式を採 用することとしている. 2 力月間の初期強化期終 了後の維持期には, 原則としてINHとRFPの 2 剂を (A)では 4 カ月，（B)では 7 カ月継続する.

結核の治療における鉄則は多剂併用である. 結核菌には一定の割合で耐性菌が含まれている ため, INHやRFPそれぞれ 1 剂の使用でも当面の 病状改善や排菌の停止は得られるが, 2〜3 カ月 のうちには薬剂耐性菌による病状の再燃をきた すものと考えるべきである，従って，活動性結 核に対しては(その疑いの場合も含め), 必ず感 受性薬剤を複数併用すべきである。なお，潜在 性結核感染症では体内の菌量がわずかであるの で 1 剂投与でよい.

標準治療に使用される薬剤およびその他の薬 剂の用法・用量は表 1 に記した. 重要なことは, これらを必要な期間継続することであり, その ために, 保健所も関わる服薬支援のシステム (日 本版DOTS）が定められている ${ }^{6)}$. 確実な服薬の ため, また薬皦の血中濃度確保の観点からも 1 日 1 回投与を原則とする. 以下，それぞれの治 療選択の条件と治療期間の設定等について以下 に述べる。

\section{1）ピラジナミドの使用の可否}

INH, RFP, PZAはそれぞれ肝障害をおこす可 能性がある薬剤であり，これらを併用すること によって更に肝障害の可能性が高まる，慢性の
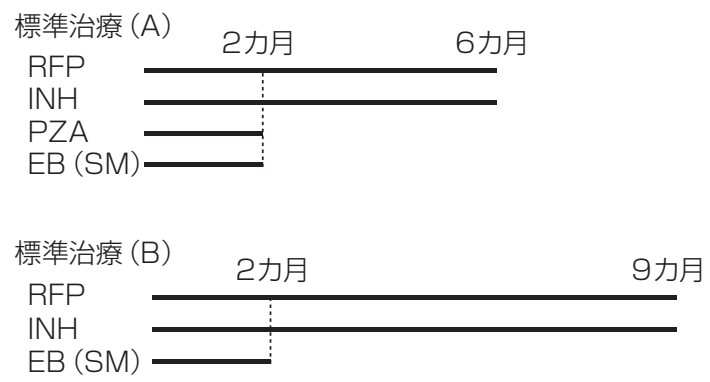

図. 結核の初回標準治療

肝疾患, 特に肝硬変や慢性C型肝炎, 80 歳以上の 高齢者では肝障害の重症化が予想されるため, また妊娠中も安全性が確認されていないため, PZAの使用は原則として避ける.

糖尿病や種々の免疫抑制状態においては, PZA を使用しなかった場合に再発時の薬剂耐性率が 高いことも報告されている7). また, PZAを使用 しない場合には治療期間は最低でも 9 力月は必 要となるので, できるだけPZAを使用するべき である。

2）エタンブトール(またはストレプトマイシ ン）の終了時期

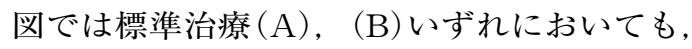
$\mathrm{EB}$ (またはSM) は初期 2 力月間使用し終了する こととしている. 最近の日本の初回治療におけ るINHとRFPの耐性率はそれぞれ $2.8 \% ， 1.0 \%$ (うち多剂耐性 $0.7 \%$ ) と報告されている ${ }^{8)}$. 当初 からINHとRFPの 2 剂のみを使用した場合, 患者 の $3.1 \%$ では有効薬剤が一つ以下となり,いずれ 多剂耐性結核になると考えなければならない. これを防ぐため, 初期にはEBまたはSMのいずれ か一剂を併用するが, INHとRFP両剂に感受性で あることが確認されれば治療開始 2 力月以内で も $\mathrm{EB}$ (またはSM) は中止してよい. ただし，治 療開始時の菌を用いた薬剤感受性検査の結果が 判明するのは培養菌が得られてから更に 2 週間 以上を要する. 2 力月時点で感受性が判明してな い場合には結果確認まで継続するのが安全であ る. 培養陰性の場合には薬剂感受性の確認がで 
表 1. 標準治療に使用する薬剈の成人の標準投与量と最大投与量（文献 2 より, 抜粋一部改変)

\begin{tabular}{|c|c|c|c|}
\hline 薬剤名 & $\begin{array}{c}\text { 標準量 } \\
\mathrm{mg} / \mathrm{kg} / \text { day }\end{array}$ & $\begin{array}{c}\text { 最大量 } \\
\mathrm{mg} / \mathrm{body} / \text { day }\end{array}$ & 備考 \\
\hline リファンピシン & 10 & 600 & \\
\hline (リファブチン) & 5 & 300 & リファンピシン使用不可の場合 \\
\hline イソニアジド & $\begin{array}{c}5 \\
<15>\end{array}$ & $\begin{aligned} & 300 \\
< & 900>\end{aligned}$ & $\begin{array}{l}\text { 小児は標準量 } 8 \sim 15 \mathrm{mg} / \mathrm{kg} \\
<>>\text { 間欠療法時 }\end{array}$ \\
\hline ピラジナミド & 25 & 1500 & \\
\hline ストレプトマイシン & 15 & 750 ( 1000$)$ & $\begin{array}{l}\text { 週 } 2 \text { 回投与の場合は } 1000 \text { mg まで可 } \\
\text { 初期 } 2 \text { ヶ月は毎日投与でもよいが } 1 \text { 日量は } 750 \text { mg まで }\end{array}$ \\
\hline エタンブトール & $15(20)$ & 750 (1000) & 最初の 2 ヶ月間は 20 mg/kg を投与してもよい \\
\hline
\end{tabular}

·投与は 1 日 1 回を原則とする

·高齢者，腎機能低下者では投与量の減量や投与間隔の延長を検討する

きないが, 症状の改善が明らかであればEB（ま たはSM）は 2 カ月で終了とする.

日本においては薬剤を長期に使用する傾向が 強かったが, INHとRFP以外の薬剂を長期に使用 することで治療成績の改善は見られず，一方で は副作用の可能性, 医療費の増大を招くので, $\mathrm{EB} \mathrm{SM} に$ 関しては適切な時期に終了することが 必要である。

\section{3）治療期間の延長の考え方}

治療期間については多くの研究により，初期 2 力月間PZA併用 6 力月治療 $((\mathrm{A})$ 法 $)$ も PZA を使用しない 9 力月治療 ( $(\mathrm{B})$ 法) も, 再発率は 0〜 2\%であり，これ以上治療期間を延長しても 再発率の低下は見られない。しかし, 有空洞 (特 に広汎空洞)例や粟粒結核などの重症例, 3 力月 目以後（初期 2 力月の治療終了後）も培養陽性 である例, 糖尿病や塵肺合併例, 全身的な副腎 皮質ステロイド薬・免疫抑制剂使用など，およ び再治療例では再発率が高いので維持期を 3 力 月延長し,（A）法は 9 力月, （B）法は 12 力月 まで行うことを検討する.

\section{4）維持期における間欠療法の導入}

結核治療において服薬の確認, 特にDOTSは重 要な要素であり,WHOのDOTS戦略は多くの国 で成果を挙げている。間欠療法は維持期の服薬 を週 3 回または 2 回とするもので, 治療成績は
毎日法に劣らないことが確認されている．ただ し，初期に標準治療が確実に実施できているこ と, HIV感染等免疫低下がないことが条件である. なお, 1 回でも服薬がされないと治療中断につな がるので，すべての服薬について医療従事者ま たは訓練された者による直接服薬確認が必要で ある。

\section{3. 標準治療ができない場合}

標準治療は最短の期間で，最良の治療成績が 得られる方法であるが，薬荗耐性がある場合， また重篤な副作用のためINH, RFPのどちらか一 つ以上が使用できない場合には，これらの薬剤 に替えて, 抗菌力は低く副作用は多い薬郕を多 数, より長期に使用する必要があり, しかも治 療成績は標準治療に劣る。外科治療も考慮する 必要がある，標準治療が行えない場合には，原 則として結核治療の専門家に相談の上治療方針 を決定することが必要である.

\section{4. 結核の治療成績}

日本における結核患者の発生状況, 治療状況, 転帰等については保健所を通じてサーベイラン スシステムにデータが入力され，年毎の分析が 
表2. サーベイランスシステムによる結核の治療

内容と成績（結核の統計 2008 年より）

a) 2007 年新登録肺結核喀痰塗抹陽性初回治療（＜wide>７9 歳) $(n=6,939)$ の治療開始内容

\begin{tabular}{l|r}
\hline \multicolumn{1}{c|}{ 治療方式 } & 患者数 \\
\hline$H R Z$ 含む 4 剤 & 5190 \\
HRZ & 53 \\
HR 含む 3 剤 & 875 \\
HR & 21 \\
HR 以外の 2 剂 & 58 \\
HR 以外の 3 剂以上 & 33 \\
H 単独 & 3 \\
H 以外の単独 & 2 \\
不明·化療なし & 504 \\
\hline
\end{tabular}

$\mathrm{H}:$ INH, R : RFP, Z : PZA

b）2006 年新登録喀痰塗抹陽性初回治療のコホート法に よる治療成績（全年齢）

\begin{tabular}{|c|c|c|}
\hline 転帰 & 患者数 & 比率 \\
\hline $\begin{array}{l}\text { 治癒 } \\
\text { 治療完了 }\end{array}$ & $\begin{array}{l}1715 \\
2824\end{array}$ & $46.4 \%$ \\
\hline 死亡 & 1846 & $18.9 \%$ \\
\hline 治療失敗 & 132 & $1.9 \%$ \\
\hline 脱落·中断 & 508 & $5.2 \%$ \\
\hline 転出 & 295 & $3.0 \%$ \\
\hline 12 ヶ月を超える治療 & 1175 & $12.0 \%$ \\
\hline 判定不能 ～～～～～～ & 1289 & $13.2 \%$ \\
\hline
\end{tabular}

行われている，最新のデータによる治療内容, 治療成績を表 2 に示した. 79 歳以下の新登録患 者の 9 割が標準治療を開始されており, 結核医 療の基準に基づいて医療内容を診査するシステ ム一感染症診査協議会が機能している結果と考え られる. 菌陰性化が確認されている「治癒」, 確 認されていないが病状改善し治療を終了した「治 療完了」をあわせた治療成功率は $46.4 \%$ に留ま り，判定不能（情報未確認）を加えても $60 \%$ に 満たない. 死亡が 2 割近くあるがその大半は高 齢者であって，化学療法は有効であっても全身 状態の改善に至らず死亡する例が多い。課題は 治療失敗, 治療の中断・脱落である. 治療の中 断・脱落は $5 \%$ 以内とするのが世界的な目標で あるが，これをやや上回る現状であり今後も DOTSの普及・徹底が必要である.
表 3. 標準治療を阻害する要因と頻度 (2006 年度 結核療法研究協議会研究報告)

\begin{tabular}{l|c|c}
\hline \multicolumn{1}{c|}{ 治療変更 } & $\begin{array}{c}\text { 症例数 } \\
\mathrm{n}=3,485\end{array}$ & $\begin{array}{c}\text { 割合 } \\
100 \%\end{array}$ \\
\hline なし & 2,645 & 75.9 \\
あり & 840 & 24.1 \\
ブランク (不明) & 158 & (除外) \\
\hline 治療変更の理由 & $\mathrm{N}=832$ & $100 \%$ \\
\hline 副作用 & 611 & 73.4 \\
薬剤耐性 & 87 & 10.5 \\
全身状態不良 & 94 & 11.3 \\
その他 & 40 & 4.8 \\
ブランク (不明) & 8 & (除外) \\
\hline
\end{tabular}

療研参加施設に2004 年の 1 年間に入院し治療開始し た初回治療肺結核患者を対象とした研究

表 4. 日本の結核入院時薬剤耐性率（単位 \%) (結核療法研究協議会, 文献 6)

\begin{tabular}{l|c|c|c|c}
\hline & \multicolumn{2}{|c|}{ 未治療耐性 } & \multicolumn{2}{c}{ 既治療耐性 } \\
\hline & 1997 年 & 2002 年 & 1997 年 & 2002 年 \\
\hline INH & 4.4 & 2.8 & 33.0 & 18.9 \\
RFP & 1.4 & 1.0 & 21.6 & 11.0 \\
SM & 7.5 & 7.0 & 24.2 & 14.4 \\
EB & 0.1 & 0.9 & 15.2 & 8.4 \\
\hline$M^{*} *$ & 0.9 & 0.7 & 19.8 & 9.8 \\
\hline
\end{tabular}

* Multi-drug resistant 多剂耐性: INH と RFP の両剂 に共に耐性

全国の結核入院施設から送付された菌を結核予防会結 核研究所において分析. 年度により協力医療機関は多 少異なる。 INH の耐性基準濃度は $0.2 \mu \mathrm{g} / \mathrm{ml}$. 各薬剂 の耐性重複有り。

また, 副作用による治療の変更も多く, 課題 の一つである．表 3 における副作用例の変更理 由は, 肝障害が半数を占め, 次いでアレルギー 症状，視力障害等であった。

結核医療の質を検証する重要な指標の一つが 薬剂耐性率である（表 4)。日本における未治療 耐性率はWHOの世界のデータの中では平均を下 回っているが, 既治療耐性はこれを上回り, INH 耐性が $18.9 \%$ ，多剂耐性が $9.8 \%$ に上っている. 未治療耐性は, 薬剂耐性患者からの感染拡大が 起きていること(公衆衛生対策の問題)を示し, 
既治療耐性は過去の治療の失敗(医療の問題)を 反映している。柾に扔ける 2002 年の耐性率 （表 4）は前回よりも低くなっており，医療の基 準に沿った標準治療の普及, 服薬支援の拡大・ 強化により状況は改善しつつあるものと考えら れる。

\section{おわりに}

地球上の結核患者は毎年 900 万人発生してお り，その大半はアジア，アフリカに存在してい る. 日本では高齢者の結核は減少しているが, 若年層における外国人患者の比率は急増してい る、世界と歩調を合わせた対費用効果がすぐれ た治療，かつ状況に応じたきめ細かい医療が求 められている.

\section{文献}

1）日本結核病学会治療委員会：「結核医療の基準」の見直 ᄂ. 結核 $77: 537-538,2002$.

2）日本結核病学会治療委員会：「結核医療の基準」の見直 し一2008 年. 結核 83（7) : 529-535, 2008.

3) ATS/CDC/IDSA : Treatment of Tuberculosis. Am J Respir Crit Care Med 167 : 603-662, 2003.

4) MMWR June 20,2003/52(RR11);1-77American Thoracic Society.

5) Treatment of Tuberculosis and Tuberculous Infection in Adults and Children. Am J Respir Crit Care Med 149: 1359-1374, 1994.

6) 厚生労働省通知：今後の結核対策の推進・強化について. 平成 15 年 2 月.

7）国立療養所化学療共同研究会：INH・RFPを主軸とする 化学療法の再排菌例の検討一国療化研第 27 次B研究報 告一. 結核 $62: 265-280,1987$.

8) Tuberculosis Research Committee(Ryoken) :Drug resistant Mycobacteirum tuberculosis in Japan: A nationwide surveillance in 2002. Int J Tuber Lung Dis 11 : 1129-1135, 2007. 